\title{
冠状動脈バイパス術後発症した virus-associated
}

\section{hemophagocytic syndrome $の 1$ 例}

牧港中央病院心臓血管外科, 同 内科*

尾形徹小渡 輝 雄*

症例は69歳, 男性. 労作性狭心症に対し冠状動脈バイパス術（CABG）を施行され順 調に経過していたが, 術後13日目, 発熱, 血痰が出現した. 胸部 X 線で右上肺野にスリ ガラス状陰影を認め間質性肺炎と診断した. 肺炎は急速に増悪して両肺野全域に広がり 呼吸状態が悪化し, acute respiratory distress syndrome (ARDS) と診断した. ステ ロイドパルス療法で間質性肺炎, ARDS は著明に改善した。一旦全身状態は改善したが 再び発熱が出現し, 汎血球減少, リンパ節腫脹を認め, 骨髄像で複数の血球を領食した 成熟した組織球が多数確認され, virus-associated hemophagocytic syndrome(VAHS) と診断した。 ただちにステロイドパルス療法を開始したが DIC, MOF を合併し死亡し た. 外科的手術を契機にVAHS が発症する例は極めて稀だが, 今後術後合併症の一つと して認識しておく必要があると考えられる.

卖引用語：VAHS, CABG, ARDS

\section{はじめに}

Virus-associated hemophagocytic syndrome (VAHS) は1979年 Risdall ら”により提唱された疾患 概念で，全身性のウイルス感染が契機として発症する 著明な血球貪食を伴う組織学的に良性な反応性組織球 増殖性疾患である。発熱, 肝脾腫, 皮疹, リンパ節腫 脹, 汎血球隇少, DIC, 黄㾝など多彩な臨床像を呈する. 一般に基礎疾患のない小児に発症することが多く自然 治痹傾向が強いとされているが, 成人発症例では免疫 不全状態を有する患者のものが多く急速に病状が悪化 し死亡する場合が多(1) 4). 外科的手術を契機に発症 する例は非常に稀で，われわれが検索した限りこれま で本邦では 1 例報告されたのみである51.今回われわ れは, 冠状動脈バイパス術後間質性肺炎で発症した VAHSのI例を経験したので報告する。

$$
\text { 症例 }
$$

症例 : 69歳, 男性.

家族歴：特記すべきことなし。

既往歴：67歳時, 薬剤性肝障害（トラニラスト）て 総ビリルビン值 $35 \mathrm{mg} / \mathrm{dl}$ まで上昇.

現病歴：1978年 8 月に冠状動脈バイパス術 (CABG)
を施行され，1995年 5 月と 8 月に左前下行枝への大伏 在静脈グラフト (SVG) の狭剺にPTCA を施行されて いる. 1997年 2 月頃より階段昇降にて胸痛が出現し始 めたため, 心蔵カテーテル検查を施行した。

心臓カテーテル検亘所見：冠状動脈造影 (CAG) て 左主幹部に $50 \%$, 左前下行枝（\#6）完全閉塞, 第一対 角枝（\#9） 90\%，回旋枝（\#13）75\%狭窄を認めた. 左 前下行枝へのグラフトは末梢吻合部に $90 \%$ の狭窄を認 めた. 右冠状動脈は（\#3）完全閉塞し，左前下行枝よ り側副血行路を認めた。左室造影にて左室駆出率は $51 \%$ った。

高度三枝病変であり，4 月25日, 再冠状動脈バイパ ス術を施行した.

手術所見：左橈骨動脈を左前下行枝に，左内胸動脈 を第一対角枝に吻合する 2 枝パイパス術を行った. 体 外循環を右大腿動脈送血, 右大腿静脈脱血で施行し, 左第 4 助間開胸で心蔵に到達した。剥離した左内胸動 脈は左前下行枝に届かず，第一対角枝に吻合し，左樈 骨動脈を左前下行枝に吻合した. 回旋枝は吻合に適し た部位が筋肉内に入りこみ見つからず，吻合を断念し た. 術中特に問題なく手術を終了した。体外循謤時間 は126分, 大動脈遮断時間は76分だった。

術後経過：術後順調に経過し，病棟内を歩行するま 
て回復していたが, 術後13日目, 発熱, 血痰が出現し た. 血圧 $116 / 62 \mathrm{mmHg}$, 脈拍 $95 /$ 分, 呼吸数 $40 /$ 分, 右 上肺野に呼吸音の減弱が認められるが,ラ音は認めず, 他には全身の理学的所見に異常を認められなかった。

検査所見：血液検査では白血球 $7.200 / \mathrm{mm}^{3}$, 赤血球 $253 \times 10^{4} / \mathrm{mm}^{3}, \mathrm{Hb} 8.4 \mathrm{~g} / \mathrm{dl}, \mathrm{Ht} 24.5 \%$, 血小板 $29.5 \times$ $10^{4} / \mathrm{mm}^{3}$, 白血球分画 (Se 71, Ly 19, Mo 9, Eo 1) と軽度貧血を認め, 生化学検査では, CRP $12.53 \mathrm{mg} /$ $\mathrm{dl}$, 総ビリルビン值 $2.9 \mathrm{mg} / \mathrm{dl}$ と上昇を認めた他は正常 範囲内であった．血液ガス分析は $\mathrm{PaO}_{2} 74.3 \mathrm{mmHg}$, $\mathrm{PaCO}_{2} 28.5 \mathrm{mmHg}$ と酸素分圧の低下がみられた。

胸部 X 線写真：右上肺野にスリガラス状陰影を認 めた（図 la).

以上より間質性肺炎と診断した。

肺炎は急速に増悪し呼吸状態が悪化したため, 発症 4 日目, 挿管し呼吸管理を行った. 挿管直後の胸部 X 線では，両側肺全域に広がるびまん性スリガラス状陰 影と air bronchogram が認められ, acute respiratory distress syndrome (ARDS) と診断した（図 1b). 病 状は急激に悪化しており，生命の危険性が非常に高く なったため, 術後感染の問題が存在したが，ステロイ ドパルス療法を行った.メチルプレドニゾロンを500 $\mathrm{mg} /$ 日 $\times 3$ 日間, $40 \mathrm{mg} /$ 日 $\times 2$ 日間投与した. ステロイ ドパルス療法後，呼吸状態は著明に改善し，血痰も消 失し, 胸部 X 線の両肺野の浸潤陰影は消失した。発熱 はパルス療法後もしばらく続いたが徐々に解熱した。 この間，血液培養，ウイルス分離は陰性であった。 た総ビリルビン値が ARDS 発症にやや遅れて上昇を はじめ, $20.4 \mathrm{mg} / \mathrm{dl}$ まで上昇したが, 肝庇護療法のみ 行い改善した。

5 月末にはほほ全身状態が改善したため, 呼吸器か らの離脱, 経口摂取の再開など離床にむけ治療を行い, 順調に回復していたが, 再度 $38^{\circ} \mathrm{C}$ 以上の発熱が出現し た. 発熱の原因は不明のまま 1 週間経過し, 血液像に て異型リンパ球および形質細胞が確認された。特に空 胞を伴ったマクロファージが多数観察された（図 2). 確定診断のため骨髄穿刺を施行したところ，骨髄像に 複数の血球を貪食した比較的成熟した組織球が多数確 認されVAHS と診断された（図 3a， b)，ただちにメ チルプレドニン $1,000 \mathrm{mg} /$ day のステロイドパルス療 法を開始したが効果なく DIC, 消化管出血, ARDS, MOF を合併し死亡した。

考察

全身性のウイルス感染を契機として発症する著明な
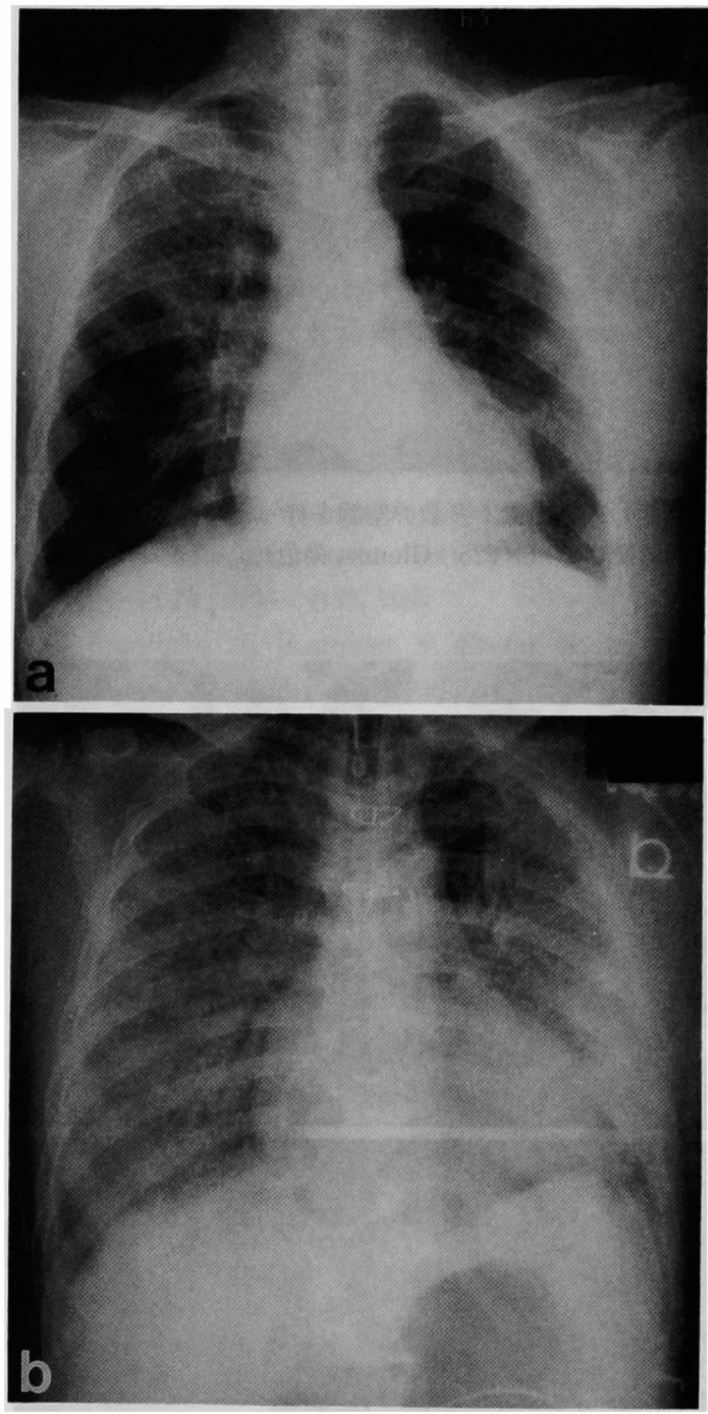

図 1 a. 胸部 X 線 : 右上肺野にスリガラス様陰影を 認める. b. 胸部 $\mathbf{X}$ 線：雨側肺全域のスリガラス様 陰影と air bronchogram を認める.

血球貪食を伴う組織学的に良性な反応性組織球増殖性 疾患を, 1979年に Risdall ら”はVAHS と呼称した. 臨 床症状は発熱, 肝脾腫, 皮疹, リンパ節腫脹, 汎血球 減少, DIC, 黄疸などを呈す. 病理所見では骨髄, リン パ節に血球貫食を伴う成熟した組織球の増殖を認め る.

原因ウイルスには EB ウイルス感染によるものが最 も多い. 本症例では, 複数のウイルス抗体価の上昇を 認めたが, ペア血清で抗体価の変動は確認できず，原 因ウイルスの特定はできなかった。 


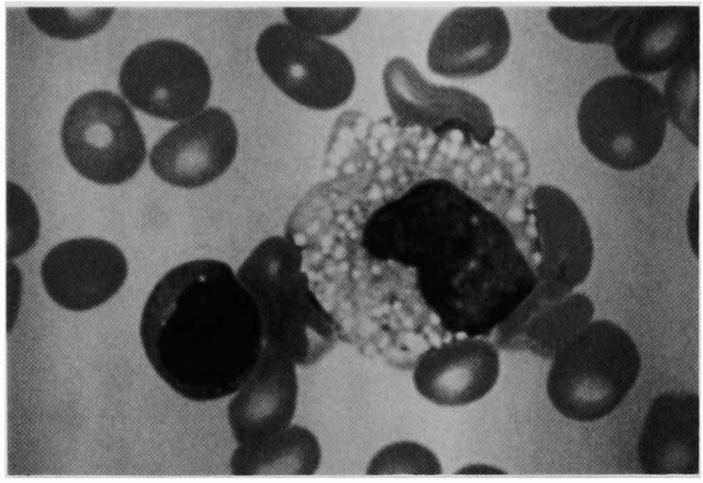

図 2 末梢血像：多数の空胞を伴ったマクロファージ を認める ( $\times 625$, Giemsa 染色).
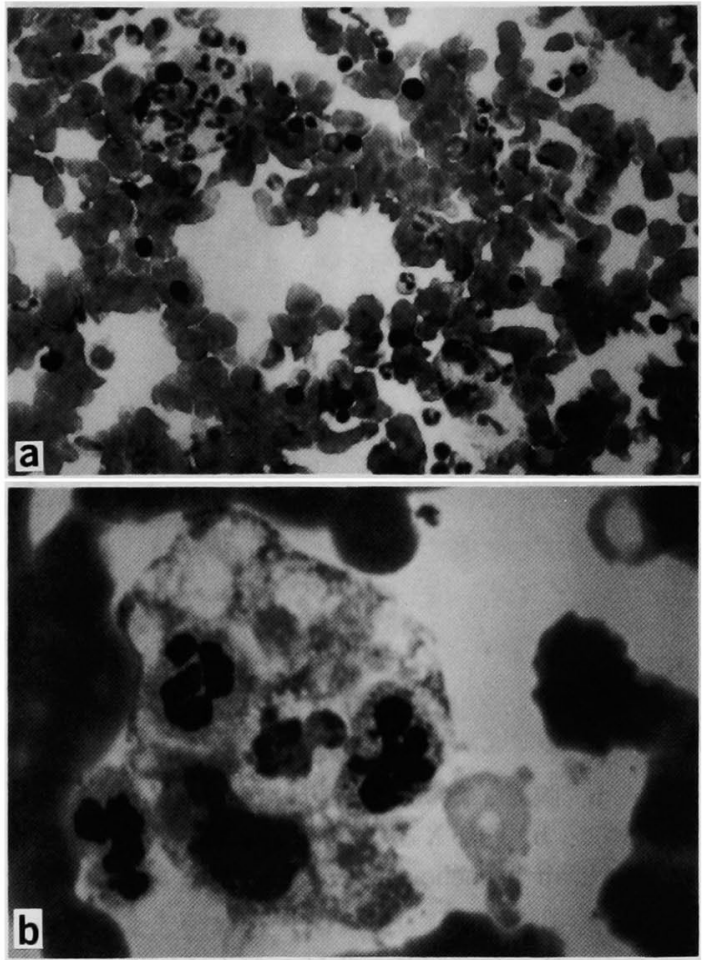

図3 a. 骨㵦像：血球貪食を伴う組織球を認める（× 250, Giemsa 染色), b. 骨髄像：組織球は比較的成 熟している (×625, Giemsa 染色).

VAHS は基礎疾患のない小児に発症することが多 く自然治痛傾向が強いとされているが，成人発症例で は基整疾患をもち免疫不全状態を有する患者のものが 多く, 急速に病状が悪化し死亡する場合が多( ${ }^{1)-4)}$.

VAHS は感染したウイルスに対する免疫調節機構
の異常 ${ }^{6}$ が原因と考えられており，ウイルス感染によ り異常に活性化された Tリンパ球やマクロファージ が分泌し生じた hypercytokinemia およびそれに伴う hemophagocytosis が種々の臨床症状を引き起こすと いわれている7.その裏づけとして,VAHS 患者の血中 サイトカインは著增しており, INF- $\gamma$, TNF, IL-1, IL-2，IL-6，可溶性 IL-2レセプター (sIL-2R)が極めて 高値をとることが報告されている899). 本症例では IL-6 が238pg/ml (正常値 $4.0 \mathrm{pg} / \mathrm{ml}$ 以下), sIL-2R が6,790 $\mathrm{U} / \mathrm{ml}$ (正常值394 $140 \mathrm{U} / \mathrm{ml}$ ) と高値であった.

治療は, 成人発症例は急速に症状が悪化し死亡する 場合が多く早期からの治療が必要である314)10)111. VAHSが異常に活性化されたTリンパ球やマクロ ファージが分泌し生じた hypercytokinemia によるも のと考えられるため, ステロイドパルス療法が一般に 行われており，著効した症例も報告されている(1)10). た， $\gamma$ グロブリンとの併用が著効を示したという報告 もある3111. 本症例ではプレドニソ゚ロンパルス療法で 間質性肺炎と ARDS が併せて治癒していることから， 肺炎の発症原因に免疫機序が大きく関与していると推 察される.VAHSに合併した間質性肺炎にステロイド 療法が著効し改善した報告もあり ${ }^{10)}$ ，また本症例は開 心術後であり免疫力の低下した状態であったといえ， 間質性肺炎が ARDSにまで発展した原因は不明たが， 肺炎およびARDSはVAHSと一連のものだったと 考えられる。また，間質性肺炎と ARDSに対し行った 最初のステロイドパルス療法は著効しているが，その 後再度施行した際には効果がなかったことはVAHS の早期診断, 早期治療の必要性が示唆される。さて, 開心術そのものを契機に ARDS が発症するケースが あるが, 重症例や体外循環時間の長い場合が多く, 術 後早期に発症する. 本症例は開心術後歩行可能にまて 回復しており，発熱，血痰を主症状にした間質性肺炎 から ARDS が発症しており，それとは異なったものと いえる。

今後, 外科的手術が契機となり発症したVAHSに 関してはステロイドパルス療法を施行する際, 術後感 染が大きな問題となることが予想される．発熱，全身 性炎症所見など呈するため新たな街後感染の有無の判 定が難しく，またVAHS 自体が免疫不全状態でのウ イルス感染による免疫機構の異常な反応が原因と考え られるため, ステロイドパルス療法施行時には常に術 後感染に対し細心の注意をもって望む必要があると考 えられる、本症例では抗生剈を併用したが，それで十 
分であったかは問題が残る.

外科的手術を契機にVAHS を発症する例は非常に まれで, 本邦においては心房中隔欠損症手術後に発症 した 1 例のみ5報告されているが, 今後VAHS の病態 がより明らかとなり早期診断率が向上するにつれ，外 科的手術が契機となったVAHS 発症例の報告は増加 してゆくと予想され，術後合併症の一つとして認識し ておく必要があると考えられる。

\section{文献}

1) Risdall RJ, McKenna RW, Nesbit ME, et al : Virus-associated hemophagocytic syndrome, a benign histiocytic proliferation distinct from malignanthistiocytosis. Cancer 44: 993-1002, 1979

2) Reiner AP, Spivak JL: Hemophagocytic syndrome. A report of 23 patients and a review of the literature. Medicine $67: 369-388,1988$

3）野村昌作, 越川佳代子, 濱本健次郎他：ステロイド と $y$ グロブリンの併用が著効を示したVirus Associated Hemophagocytic Syndrome $の 1$ 例. 臨 血 $33: 1242-1247,1992$

4) 吉村典子, 西岡新吾, 谷田 徹他：Epstein-Barr virusによると思われる Virus-associated hemophagocytic syndrome の 1 例と本邦成人例の検 討. 感染症誌 65 : 472-476, 1990
5）堀越 衛, 秋山謙次, 小笠原弘二他：手術後に血球 頜食症候群を呈した左上大静脈遗残合併心房中隔 欠損症の 1 治験例。臨外 $50: 573-576,1997$

6) McClaub $\mathrm{K}$ : Ebstein-Barr virus DNA in lymphocytes of patients with the virus a ssociated hemophagocytic syndrome. Am J Pediatr Hematol Oncol 8 : 121-127, 1986

7) 今宿晋作：血球貪食症候群(Hemophagocytic syndrome, HPS). 日小児血液会誌 $5: 349-360$ ， 1991

8) Komp DM, McNamara J, Buckley P: Elevated soluble interleukin-2 receptor in childhood hemophagocytic histiocytic syndrome. Blood 73 : 2128-2132, 1989

9) Imashuku $S$, Ikushima $S$, Esumi $N$, et al : Serum levels of in terferon-gamma, cytotoxic factor and soluble interleukin-2 receptor in childhood hemophagocytic syndrome. Leukemia and lymphoma $3: 287-292,1991$

10）高柳典弘, 幸田久平, 平山泰生地：間質性肺炎を伴 ったvirus-associated hemophagocytic syndrome の成人例. 臨血 $35: 682-688,1994$

11）丸澤宏之, 濱本健次郎 他：風疮ウイルスによると 思われる virus-associated hemophagocytic syndrome の成人例. 臨血 $35: 576-580,1994$

\title{
A CASE OF VIRUS-ASSOCIATED HEMOPHAGOCYTIC SYNDROME AFTER CORONARY ARTERY BYPASS GRAFTING
}

\author{
Toru OGATA and Teruo KOWATARI* \\ Department of Cardiovascular Surgey and Internal Medicine*, Makiminato Central Hospital
}

A 69-year-old man who underwent coronary attery bypass grafting (CABG) for effort angina with an uneventful clinical course developed hemoptysis and fever on the 13th postoperative day. Chest X-ray showed interstitial pneumonia. the pneumonia spread quickly over the entire lung fields, and respiratory function worsened. The patient was diagnosed with having acute respiratory distress syndrome (ARDS). Steroid therapy was initiated and the patient responded very well. Remarkable remission in pneumonia and ARDS attained. General condition once improved, but 2 weeks later, fever appeared again and reevalution revealed pancytopenia and lymphadenopathy. Bone marrow examination revealed hemophagocytosis by mature histiocytes, therefore he was diagnosed as virus associated hemophagocytic syndrome (VAHS). Steroid therapy was immediately started again, but the patient died of disseminated intravascular coagulation and multiple organ failure.

This is a very rare case of VAHS due to surgical stress. It is suggested that VAHS must be recognized as a probable postoperative complication. 